\title{
Regulatory and institutional mechanism for the implementation of the goals of sustainable development of the region
}

\author{
Tatiana Alferova* \\ Perm National Research University, 614068, Perm, Russia
}

\begin{abstract}
The mechanism for ensuring sustainable development of regions should be carried out according to the principle of localization, according to which seventeen global development goals are initially detailed in the national context, and then reflected in regional projects and programs. Currently, there is an imbalance in global, national and regional instruments for achieving sustainable development, which requires clarification of the reasons for the current situation. The achievement of the SDGs in the regions is usually implemented by the program-targeted method, which allows directing specific resources to solving specific development issues. Management is concentrated in the relevant structures that consider the specifics of the problems and the essence of the mechanisms for implementing planned activities. However, there is no link between program targets, national sustainable development targets and global SDGs. There is also a duplication of some indicators in different programs and the intersection of a number of areas of socio-economic development of the region. The programs are designed for different periods of implementation, but do not take into account the cause-and-effect chains of desirable / undesirable effects, they are not linked to each other in terms of the totality of program activities, and do not engage synergy effects. This task requires a comprehensive solution with the accumulated experience at the country level by adapting existing and developing new methods for modeling the socio-ecological-economic systems of the regions.
\end{abstract}

\section{Introduction}

The mechanism for ensuring sustainable development of regions in accordance with the resolution of the UN General Assembly A/RES/71/313 of July 6, 2017, should be implemented according to the principle of localization, according to which the seventeen SDGs of the 2030 Agenda for Sustainable Development from a list of national indicators for achieving the SDGs based on national priorities, local conditions and available statistical capacity. In the future, this set should be used to prepare regional strategies and / or programs. At the same time, local and regional authorities are seen as key partners in achieving the SDGs on a bottom-up basis (Fig. 1).

\footnotetext{
*Corresponding author: talferova68@mail.ru
} 


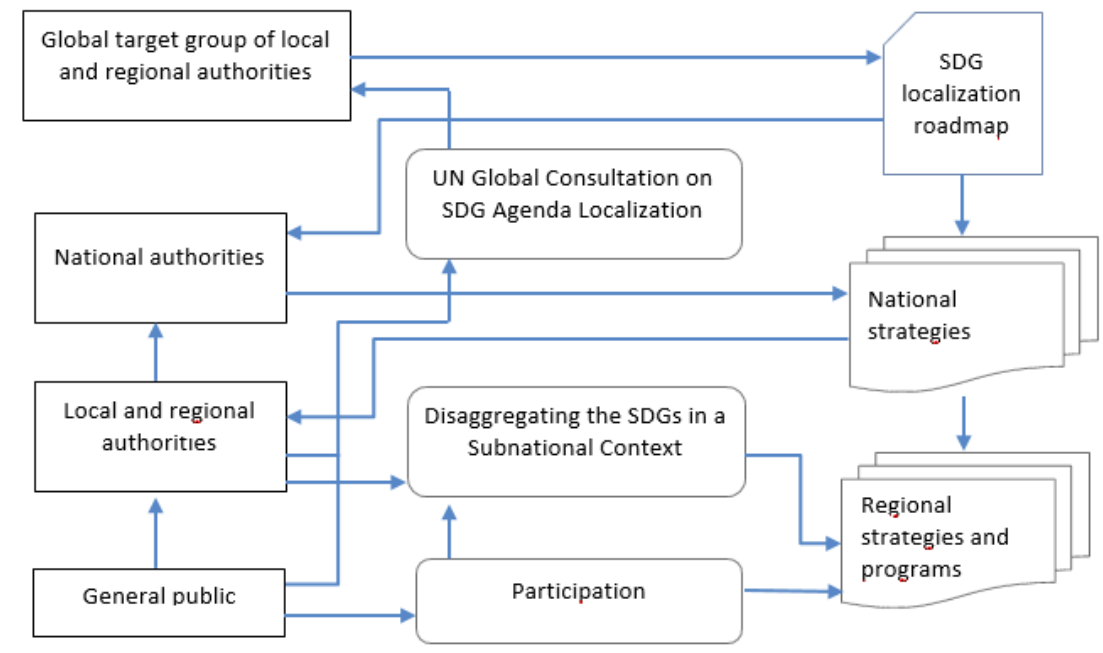

Fig. 1. A bottom-up architecture for localizing SDGs to the subnational level.

Source: Compiled by the author.

The national set of SDG indicators for Russia is determined by the Decree of the President of the Russian Federation of May 7, 2018 No. 204 "On national goals and strategic objectives of the development of the Russian Federation for the period up to 2024", strategic documents of the Government of the Russian Federation, national and federal projects. Since in the Perm Territory there is no unified strategy for the sustainable development of the region, adapted to the national SDG indicators, the main documents underlying the issue under study can be considered the Law of the Perm Territory "On strategic planning of the socio-economic development of the Perm Territory" and "Strategy of socio-economic development of the Perm region until 2026". The document defined the "Program of socio-economic development of the Perm Territory for 2012-2016" as the main mechanism for the implementation of the Strategy.

\section{Research methodology}

In October 2013, twenty state programs were approved for a total amount of 1,379,262,982 thousand rubles. The programs entered into force on 01/01/2014, with implementation periods ranging from three to ten years. The implementation is provided by the programtarget method. Table 1 presents the results of a comparative analysis of methods for assessing the effectiveness of programs. 
Table 1. Criteria for the effectiveness of state programs of the Perm region.

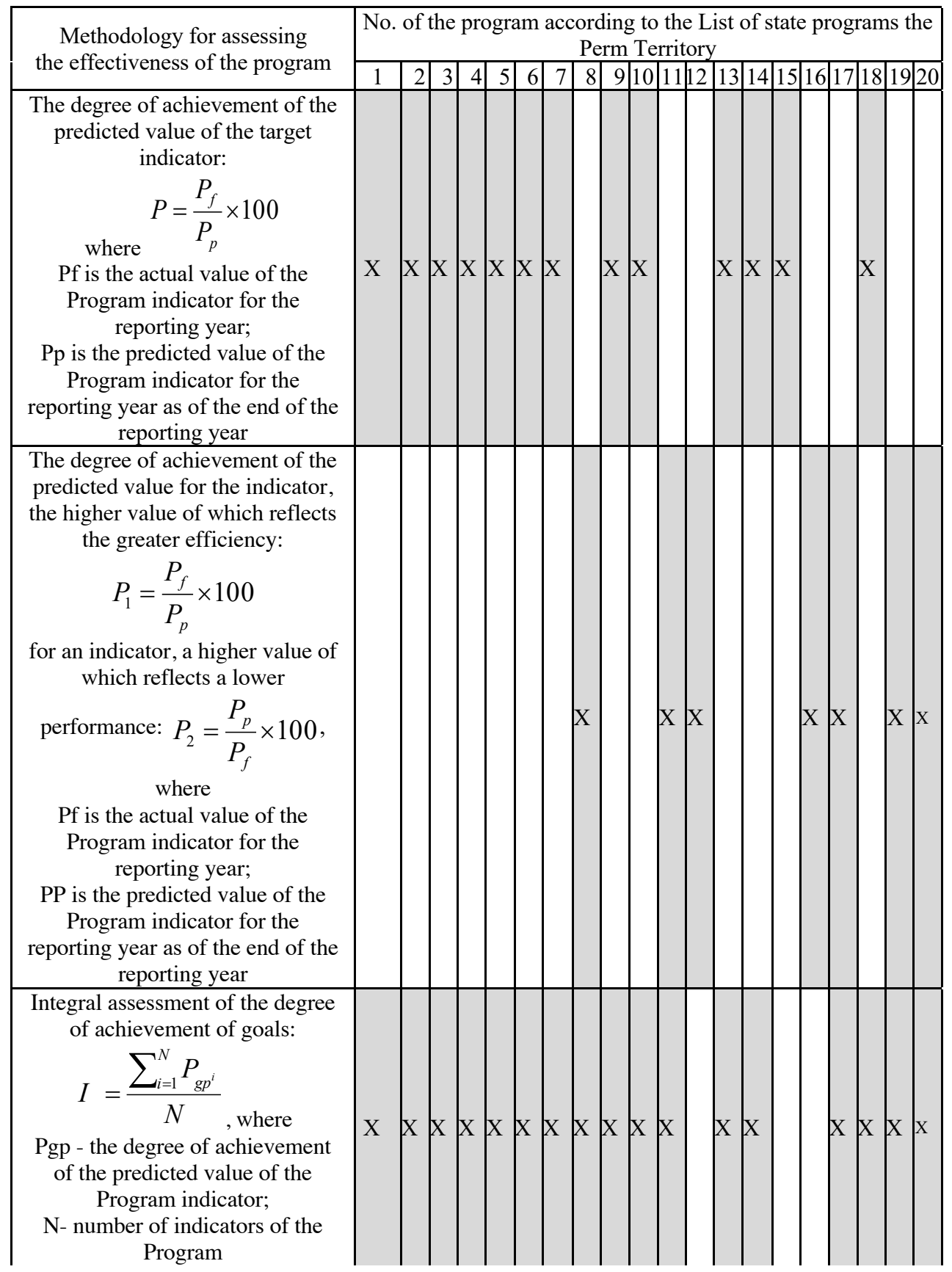


Continuation of table 1 .

Disbursement rate: $D R=\frac{F_{f}}{F_{p}}$ where

Ff- actual expenses for the implementation of the Program for the reporting financial year; $\mathrm{Fp}$ - the planned expenses estimated for the implementation of the Program as of the end of the reporting financial year

The degree of compliance with the planned cost level:

$$
C=\frac{\sum_{i=1}^{n} M_{f_{t}} / M_{p_{I}}}{n} \times 100 \%
$$
where

Mf - the amount of funds actually spent on the event during the implementation of the Program; $\mathrm{Mp}$ - the amount of funds planned for the implementation of the

Program activities;

n- number of events of the Program

Financing performance level: $Y=\frac{\left(F_{f}+F_{e}\right)}{F_{p}} \times 100 \%$, where: Ff is actually spent amount of funds directed

for the implementation of the Program for the reporting period, rubles;

$\mathrm{Fe}$ is for savings (as a result of competitive procedures) of funds for the reporting period, rubles; $\mathrm{Fp}$ is the planned amount of funds for the corresponding reporting period, rubles.

The degree of efficiency of tax expenditures under the Program:

$$
E_{N R}=\frac{\sum_{i=1}^{N} E_{N R^{i}}}{N} \text { where }
$$

ENRi - the efficiency of the tax expenditure of the Perm Territory within the framework of the

Program (if there is efficiency, the value is taken equal to 1 , in the absence of efficiency, the value is taken equal to 0 )
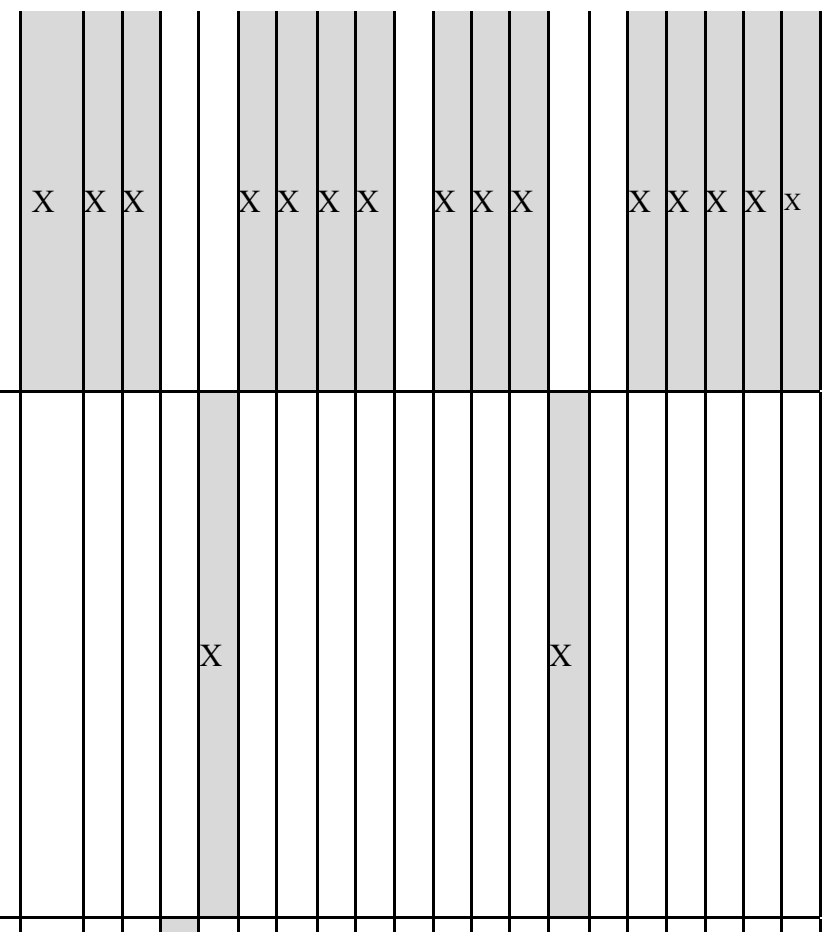

(


Continuation of table 1.

Comprehensive assessment:

$E_{C A}=\sum_{i=1}^{N} Z K_{i} \times B K_{i}$, where

$\mathrm{ZKi}$ - the value of the Program

efficiency criterion (from 0 to 1 );

$\mathrm{BKi}$ - weight in the assessment of the criterion of the effectiveness

of the Program (up to 100\%)

Final estimate: $F E=\frac{\sum Z_{1}-n_{e}}{n_{e}}$,

where

Z- expert's assessment on the achievement of the assigned task; $\mathrm{n}$ - the number of experts (e) who

participated in expert survey

The effectiveness of the implementation of the program (subprogram):

$E I P=S D C \times U V$, where

SDC - the degree of achievement of goals (solving problems);

UV - the level of funding for the implementation of the main activities of the Program (subprogram)

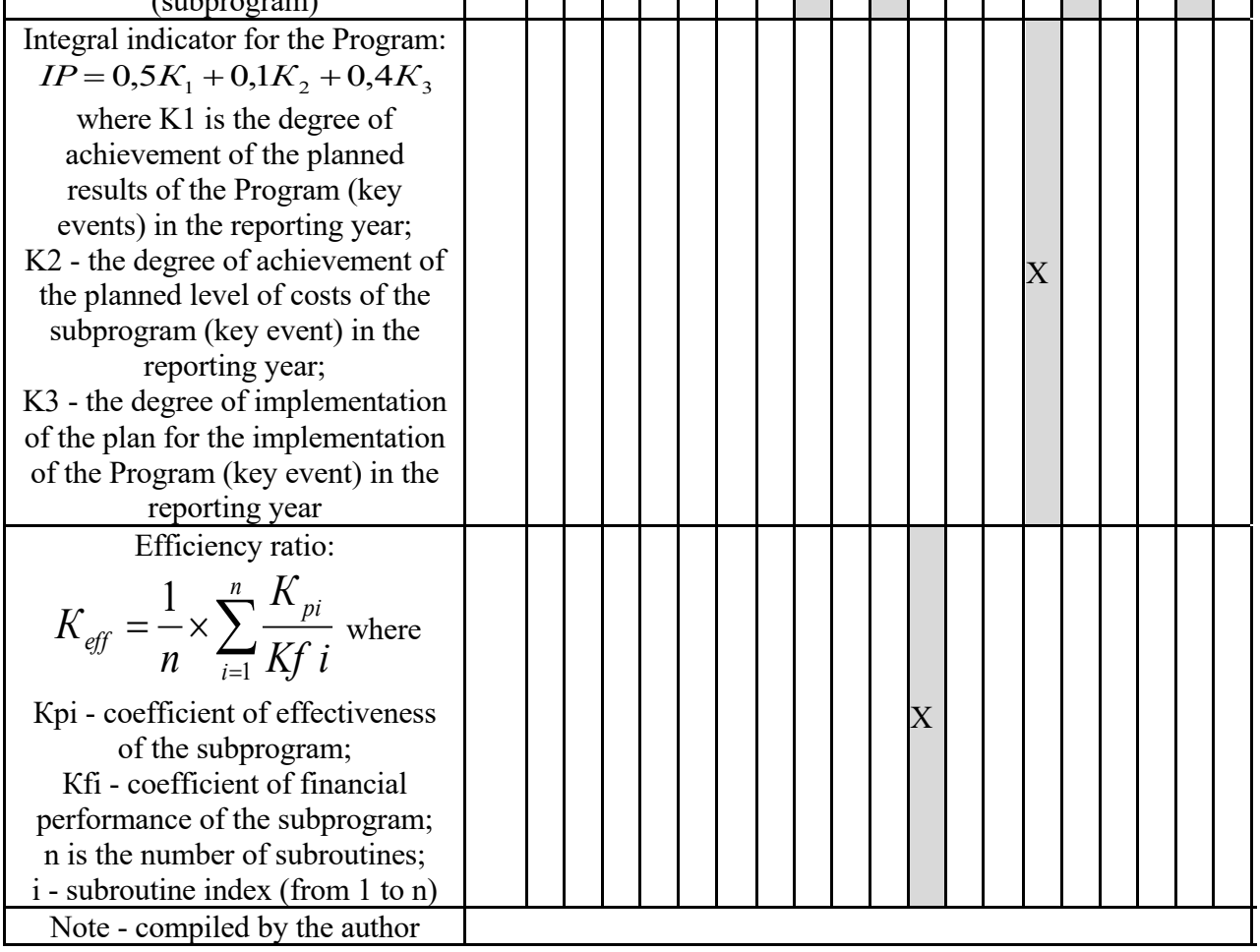

This approach involves the development of the region through the parallel implementation of autonomous state programs that have their own targets (outputs), funding 
(inputs), management entities (regional ministries and departments), management objects (program executors) (Fig. 2). For programs of an interdepartmental and public nature, Coordination Councils have been formed.

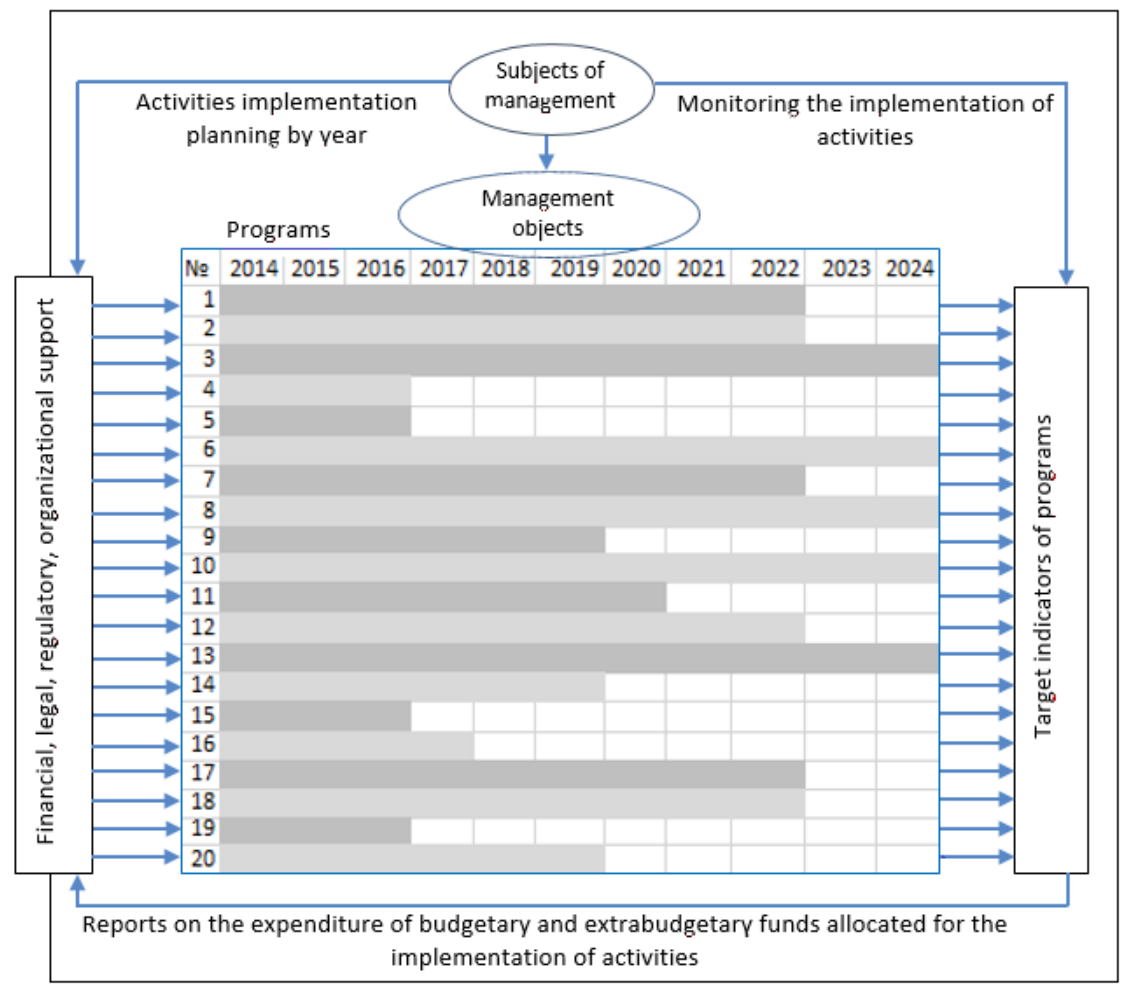

Fig. 2. Model of ensuring the socio-economic development of the region.

Source: Compiled by the author.

This approach allows directing specific resources to solving specific development problems, management is concentrated in the appropriate structures that understand the specifics of the problems and the essence of the mechanisms for implementing planned activities. However, there is no link between program targets with each other, national sustainable development targets and global SDGs. There is also a duplication of some indicators in different programs and the intersection of a number of areas of socio-economic development of the region. The programs are designed for different periods of implementation, but they ignore the cause-and-effect chains of desirable / undesirable effects, they are not linked to each other in terms of the totality of program activities. In addition, synergies are not taken into account, which are important for optimizing resources (inputs), processes and maximizing results (outputs).

\section{Research results}

The very principle of designing programs limits the possibility of achieving synergistic effects (Table 2); this also explains the insufficient elaboration of the issue of synergy in the context of the SDG policy, since there is currently no broad quantitative analytical basis for assessing the synergy of regional programs in the context of achieving the SDGs. 
Table 2. Synergistic effects of different types of synergy in the implementation of regional development programs.

\begin{tabular}{|c|c|c|c|}
\hline Synergy type & Synergistic effect & Restrictions & Author \\
\hline Resource & $\begin{array}{l}\text { Sharing resources, } \\
\text { infrastructure facilities, } \\
\text { etc., reduce the cost of } \\
\text { their acquisition and } \\
\text { maintenance }\end{array}$ & $\begin{array}{c}\text { Programs have unequal } \\
\text { duration of } \\
\text { implementation Responsible } \\
\text { executors are ministries and } \\
\text { departments }\end{array}$ & $\begin{array}{l}\text { Pazdnikova N.T. } \\
\text { Omarov T.D. } \\
\text { Morgunova N.V. } \\
\text { Sinyavsky D.A. }\end{array}$ \\
\hline Managerial & $\begin{array}{c}\text { Exchange of management } \\
\text { experience, increasing the } \\
\text { efficiency and } \\
\text { effectiveness of } \\
\text { management decision- } \\
\text { making }\end{array}$ & $\begin{array}{c}\text { Responsible program } \\
\text { executors are different } \\
\text { ministries and } \\
\text { departments. Programs are } \\
\text { linked to different priorities } \\
\text { and goals of public policy in } \\
\text { different directions of } \\
\text { regional development } \\
\end{array}$ & Kasyanenko T.G. \\
\hline Operational & $\begin{array}{l}\text { Joint use of opportunities } \\
\text { (specialization, } \\
\text { cooperation, etc.) and } \\
\text { production resources } \\
\text { reduces their consumption } \\
\text { and impact on the } \\
\text { environment } \\
\end{array}$ & $\begin{array}{l}\text { Programs relate to different } \\
\text { sectors of the economy, in } \\
\text { addition, not all of them are } \\
\text { related to production }\end{array}$ & $\begin{array}{c}\text { Yarembash A.I. } \\
\text { Kokhan N.V. } \\
\text { Kharitonov A.V. }\end{array}$ \\
\hline $\begin{array}{l}\text { Financial / } \\
\text { investment }\end{array}$ & $\begin{array}{l}\text { Savings are created by } \\
\text { changing funding sources, } \\
\text { funding costs and other } \\
\text { benefits }\end{array}$ & $\begin{array}{c}\text { Programs are mainly } \\
\text { financed with regional } \\
\text { budgets, and to a lesser } \\
\text { extent with the federal } \\
\text { budget. Extrabudgetary } \\
\text { sources make up the smallest } \\
\text { share }\end{array}$ & $\begin{array}{l}\text { Yarembash A.I. } \\
\text { Kokhan N.V. }\end{array}$ \\
\hline Social & $\begin{array}{l}\text { Raising the level of } \\
\text { professionalism, moral } \\
\text { responsibility } \\
\text { personnel contributes to } \\
\text { the constructive } \\
\text { development of } \\
\text { cooperation between the } \\
\text { state and market structures }\end{array}$ & $\begin{array}{l}\text { The impact is difficult to } \\
\text { quantify, there is no clear } \\
\text { framework and estimates of } \\
\text { the development potential of } \\
\text { program participants }\end{array}$ & $\begin{array}{l}\text { Betilgiriev I.M. } \\
\text { Betilgiriev M.A. } \\
\text { Taymaskhanov } \\
\text { Kh.E. }\end{array}$ \\
\hline $\begin{array}{l}\text { Program } \\
\text { contents }\end{array}$ & $\begin{array}{l}\text { Optimization of regional } \\
\text { programs according to the } \\
\text { criterion of achievement } \\
\text { goals and ensuring a } \\
\text { balance between federal, } \\
\text { regional and departmental } \\
\text { programs serves } \\
\text { elimination of duplicate } \\
\text { activities, consolidation of } \\
\text { resources, more efficient } \\
\text { use of budget funds, } \\
\text { human capital, } \\
\text { information, etc. }\end{array}$ & $\begin{array}{l}\text { Target programs do not } \\
\text { always have a cross-cutting } \\
\text { nature; sets of programs at } \\
\text { the federal and regional } \\
\text { levels are not always linked } \\
\text { to each other in terms of } \\
\text { goals, objectives and a set of } \\
\text { program activities }\end{array}$ & $\begin{array}{l}\text { Omarov T.D. } \\
\text { Morgunova N.V. } \\
\text { Sinyavsky D.A. }\end{array}$ \\
\hline
\end{tabular}


Continuation of table 2 .

\begin{tabular}{|c|c|c|c|} 
Distributive & $\begin{array}{c}\text { The effect of combined } \\
\text { production, processing and } \\
\text { marketing of products, } \\
\text { joint use of logistics } \\
\text { networks is expressed by } \\
\text { reducing costs and } \\
\text { increasing profitability }\end{array}$ & $\begin{array}{c}\text { Applicable only for the } \\
\text { implementation of targeted } \\
\text { programs aimed at the } \\
\text { development of specific } \\
\text { industries or areas of activity } \\
\text { related to the production and } \\
\text { sale of products }\end{array}$ & Kharitonov A.V. \\
\hline NOTE - Compiled by the author
\end{tabular}

\section{The discussion of the results}

The problem of studying synergistic effects in regional development programs is not new, especially with an emphasis on specific thematic areas: industrial production (Golev A.V., Cherny S.A. [1]), agriculture (Sergeev P.V., Bredikhin V.V., Polozhentseva Yu.S. [2], Kharitonov A.V. [3]), innovations (Shevyrev M.M. [4]). The sectoral or departmental community, the uniformity of the resources and infrastructure used, the similarity of goals and management methods make it possible to use the existing tested tools to assess synergistic effects. In most cases, it is used to convey the same fundamental principle: a combination of different actions or elements reinforces each other, leading to a result greater than the sum of their individual influences [5]. To overcome the above and other limitations, more complex methodological approaches and principles of the program-target approach are used (using maps of target programs, creating focal points, etc.).

The search for opportunities to take into account synergistic effects in a complex of different programs was also undertaken and implemented in the works of Omarov T.D., Morgunova N.V., Sinyavsky D.A. [6], Yarembasha A.I., Kohana N.V. [7], Pazdnikova N.T. [8] and others.

The SDG synergy methodology is shaped mainly at the country level. Since the systems under study have a high combinatorial complexity, determined by the number of connections between elements, the size of the search space, contradictions in the interaction of agents, the passage of time, etc., to study the synergy of SDGs at the global level of countries, the models of system dynamics Threshold 21 [9], World 3 [10] and research Limits to Growth [11], because they allow for time delays and allow for circular causation. M. Pedercinia, S. Arquitta, D. Collstea et.al [12] proposed the iSDG (Integrated Sustainable Development Goals) model, developed on the basis of the Threshold 21 model. A. Karnib [13], A. Bojtor, K. Czippán [14] also proposed multicriteria modeling of sustainable development policy options. However, there are practically no tools suitable for assessing synergy in the implementation of sustainable development programs for regional systems.

Cognitive models can serve as a basis for a deeper understanding of the sources of the SDG synergies of regional systems to show how synergies arise during the implementation of programs, projects or regional policies. A simple chain of results can describe each program. This general management tool is widely used at the global level, in particular World Bank [15], Millennium Institute [16], etc.

M. Pedercinia, S. Arquitta [8, p.23023], identify five fundamental mechanisms that can potentially lead to a synergistic effect at different stages of the chain of results. Type I synergy arises from changes in inputs, for example, the financial resources available to implement one intervention are triggered by the implementation of another intervention. Type II synergy occurs when the implementation of a political intervention changes the immediate results of another intervention, influencing its favorable conditions. Type III synergy occurs when an intervention in one sector affects the target group of another intervention. Type IV synergy occurs when associated interventions are characterized by 
increases or decreases in marginal returns. Type V synergy is a special case of Type IV synergy, it occurs when progress on an indicator cannot or should not exceed a given target value. When simulating a large number of expected policy interventions, the net synergy obtained can be determined by a combination of synergistic effects of different types or polarities. In such cases, modeling should be done in stages: first include only pairs of interventions, then gradually expand the number of interventions until a complete strategy is modeled. Through this process, not only can the overall net synergy be assessed, but also the understanding of the sources of this synergy can be enhanced. Failure to understand possible synergistic interactions between political interventions can easily lead to undesirable results and suboptimal use of resources [6].

This approach can be used for the regional level after adaptation to the specifics of regional sustainable development programs.

\section{Conclusions}

Exploring the synergistic effects of the region is a complex task requiring coordinated action across a whole set of regional policies and, at the same time, alignment with the global SDG agenda. At the same time, it is necessary to consider various types of synergies that give different synergistic effects. This task requires a comprehensive solution regarding the accumulated experience at the country level by adapting existing and developing new methods for modeling the socio-ecological-economic systems of the regions.

\section{References}

1. A. V. Golev, S. A. Chernyi, Economic prospects for the joint use of resources in large industrial centers, Bulletin of UGAES. The science. Education. Economy. Series: Economics, 2, 63-67 (2012)

2. P. V. Sergeev, V. V. Bredikhin, Yu. S. Polozhentseva, Management of innovative development of agrarian regions based on a program-targeted approach, Bulletin of the Kursk State Agricultural Academy (2018). Access mode: https://cyberleninka.ru/article/n/upravlenie-innovatsionnym-razvitiem-agrarnyhregionov-na-osnove-programmno-tselevogo-podhoda / viewer

3. A. V. Kharitonov, Synergetic approach to sustainable development of agriculture in the

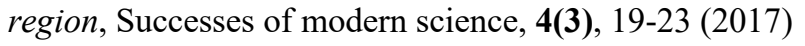

4. M. M. Shevyrev, On the methodology for determining the synergistic effect of innovative regional clusters, Economics and Management, 3 (53), 36-40 (2010)

5. M. Pedercinia, S. Arquitta, D. Collstea, H.Herren, Harvesting synergy from sustainable development goal interactions, Sustainability Science (2019). Access mode: https://www.pnas.org/content/116/46/23021

6. T. D. Omarov, N. V. Morgunova, D. A. Sinyavsky, Approaches to assessing the synergistic effect of federal and regional target programs (on the example of the Vladimir region), Economics and Politics, 6, 11-16 (2013)

7. A. I. Yarembash, N. V. Kokhan, Synergy effect in regional socio-economic development programs, Conference collection: "Mechanisms for managing economic, environmental and social processes in the context of innovative development.", 310-318 (2017)

8. N. P. Pazdnikova, Methodology of program-targeted management of regional socioeconomic systems based on the formation of comprehensive monitoring of state 
programs. Dissertation. Specialty 08.00 .05 , Economics and National Economy Management: Regional Economics, 40 (2015)

9. M. Pedercini, G. Barney, Dynamic analysis of interventions designed to achieve millennium development goals (MDG): The case of Ghana, Socioecon. Plann. Sci., 44, 89-99 (2010)

10. D. H. Meadows, D. L. Meadows, J. Randers, W. W. Behrens, The Limits to Growth: A Report for the Club of Rome's Project on the Predicament of Mankind (1972)

11. D. H. Meadows, J. Randers, D. L. Meadow, Limits to Growth: The 30-Year Update. London. Chelsea Green Publishing, ed. 3 (2004)

12. M. Pedercinia, S. Arquitta, D. Collstea, H. Herrena, Harvesting synergy from sustainable development goal interactions. PNAS, 116, 46 (2019)

13. A. Karnib, A Quantitative Nexus Approach to Analyze the Interlinkages across the Sustainable Development Goals, Lebanese University, Hadath Campus, Baabda, Lebanon (2017). Access mode: https://doi.org/10.5539/jsd.v10n5p173

14. A. Bojtor, K. Czippán, The Synergies of the Sustainable Development Goals and the Good State and Governance Report in Hungary (2019). Access mode: https://www.nispa.org/files/conferences/2019/e-proceedings/system_files/papers/thesynergies-bojtor.pdf

15. World Bank, World Development Indicators database (2017). Access mode: https://datacatalog.worldbank.org/dataset/world-development-indicators

16. Millennium Institute, Official documentation of the iSDG model (Millennium Institute, 2017). Access mode: https://www.millennium-institute.org/documentation 